\title{
Investigation of cell culture conditions for optimal foot-and-mouth disease virus production
}

\author{
Veronika Dill ${ }^{1}$, Aline Zimmer $^{2}$, Martin Beer ${ }^{1}$ and Michael Eschbaumer ${ }^{1 *}$ (D)
}

\begin{abstract}
Background: Foot-and-mouth disease is a highly contagious and economically devastating disease with endemic occurrence in many parts of the world. Vaccination is the method of choice to eradicate the disease and to limit the viral spread. The vaccine production process is based on mammalian cell culture, in which the viral yield varies in dependence of the composition of the culture media. For foot-and-mouth disease virus (FMDV), very little is known about the culture media components that are necessary to grow the virus to high titers in cell culture.

Results: This study examined the influence of increasing concentrations of glucose, glutamine, ammonium chloride and different cell densities on the yield of FMDV. While an excess of glucose or glutamine does not affect the viral yield, increasing cell density reduces the viral titer by a $\log _{10}$ step at a cell density of $3 \times 10^{6}$ cells $/ \mathrm{mL}$. This can be mitigated by performing a 100\% media exchange before infection of the cells.

Conclusions: The reasons for the diminished viral growth, if no complete media exchange has been performed prior to infection, remain unclear and further studies are necessary to investigate the causes more deeply. For now, the results argue for a vaccine production process with 100\% media exchange to reliably obtain high viral titers.
\end{abstract}

Keywords: Foot-and-mouth disease virus, Vaccine, Glucose, Glutamine, Cell density, Suspension cells, Animalcomponent free

\section{Background}

Foot-and-mouth disease (FMD) is a viral disease of clovenhoofed livestock with tremendous economic impact [1]. Every year, more than one billion doses of FMD vaccine are produced worldwide [2]. These vaccines are used for control programs in regions where FMD is endemic and for the emergency response to outbreaks in areas where the disease does not occur regularly $[2,3]$.

Mammalian cells are widely used for the propagation of viruses for vaccine production. The viral yield in cell culture varies greatly depending on the composition of the culture media [4]. For instance, the production of poliovirus in HeLa cells differs with the media composition, with salts, glucose and glutamine representing the only essential substrates for successful virus production $[4,5]$. Glucose and glutamine are the main carbon

\footnotetext{
* Correspondence: michael.eschbaumer@fli.de

${ }^{1}$ Institute of Diagnostic Virology, Friedrich-Loeffler-Institut, Südufer 10, 17493

Greifswald, Insel Riems, Germany

Full list of author information is available at the end of the article
}

sources for mammalian cells in culture. They are key nutrients to cover the cell's energy requirements [6]. The glycolysis and glutaminolysis pathways in the cell are utilized at high rates to metabolize these substrates, leading to the production of high amounts of waste products such as lactate and ammonium [7]. Many viral infections are characterized by an increase in the rate of glycolysis, e.g. poliomyelitis virus [8], feline leukemia virus [9], or herpes simplex virus [10] or an increase in glutamine uptake, e.g. vaccinia virus [11] or human cytomegalovirus [12]. In addition to these two important pathways, a viral infection of the cell leads to other changes in the cellular metabolism, such as fatty acid synthesis [13, 14].

For foot-and-mouth disease virus (FMDV), very little is known about the culture media components that are necessary to grow the virus to high titers in cell culture. An early study by Pledger et al. [15] named glucose as an important substrate for FMDV replication, while glutamine alone had no influence on the viral titer. 
However, the metabolism of glucose produces high amounts of lactate that are released into the culture media, decreasing its $\mathrm{pH}$ if the buffer capacity of the media is exceeded $[13,16]$. Optimizing the glucose and glutamine content of the culture media can increase the viral harvest, while the use of increased cell densities allows a more efficient use of bioreactor capacity and decreased costs per dose of vaccine [16]. Using animalcomponent free (ACF) media for vaccine production can further reduce costs and minimize the risk of contamination through animal-derived raw materials [3, 17].

This study investigated the metabolism of baby hamster kidney (BHK) suspension cells infected with the recent FMDV isolates A IRN/8/2015 and O SAU/18/2015. The viral titer as well as the effect of different concentrations of glucose, glutamine and ammonium chloride in the medium were examined. Furthermore, infection at different cell densities in combination with a total or partial media exchange was compared.

\section{Results}

Abundant glucose and glutamine in the cell culture media does not increase the viral yield

Infection studies of BHK-2P suspension cells were performed using the recent FMDV isolates A IRN/8/2015 and O SAU/18/2015 and increasing concentrations of glucose and glutamine in the cell culture media. Independently of the glucose or glutamine concentration, stable virus titers of $7.7 \pm 0.2 \log _{10} \mathrm{TCID}_{50} / \mathrm{mL}$ across the different glucose concentrations and $7.9 \pm 0.1 \log _{10}$ $\mathrm{TCID}_{50} / \mathrm{mL}$ across the different concentrations of glutamine were achieved for A IRN/08/2015, compared to $7.2 \pm 0.1 \log _{10} \mathrm{TCID}_{50} / \mathrm{mL}$ and $7.3 \pm 0.1 \log _{10} \mathrm{TCID}_{50} /$ $\mathrm{mL}$ for O SAU/18/2015, respectively (Fig. 1).

No statistically significant differences in the content of glutamine and glucose in the cell culture media before and after viral infection were observed in any of the tested conditions for either virus isolate (Fig. 2).

Cell viability in the infected cultures dropped drastically after 20 hpi compared to the uninfected negative controls in all experiments (see Additional file 1). The amounts of lactate accumulated in the media of the infected cultures were 10 to $60 \%$ lower (depending on serotype and tested condition) in comparison to the negative control. Nevertheless, among the infected cultures, no statistically significant difference between the tested conditions was detected (Fig. 2).

In general, the cells consumed only a small fraction of the available carbohydrates when infected with FMDV based on the differences in the glucose and glutamine content of the media before and after viral infection independent of the total concentration of glucose or glutamine in the media. The difference in concentration of glutamine and glucose for the respective negative controls was nearly twice as much than for the infected cells (Table 1).

Calculations of the cell-specific glucose uptake rates revealed a positive trend of an increased glucose consumption with increased glucose availability when infected with FMDV serotype A that was not evident for cells infected with serotype $O$ (see Additional file 3: Table S3). On the other hand, the data for the cellspecific glutamine uptake suggest an increased uptake of glutamine with increasing concentrations of glutamine available in the cell culture media when infected with serotype $\mathrm{O}$, while no trend was evident for serotype-Ainfected cells (see Additional file 3: Table S4).

The concentration of ammonium chloride in the cell culture media influences cell survival but not the viral yield

The ACF media was supplemented with increasing concentrations of ammonium chloride ranging from $0 \mathrm{mM}$ to $12 \mathrm{mM}$ and cells were infected with A IRN/

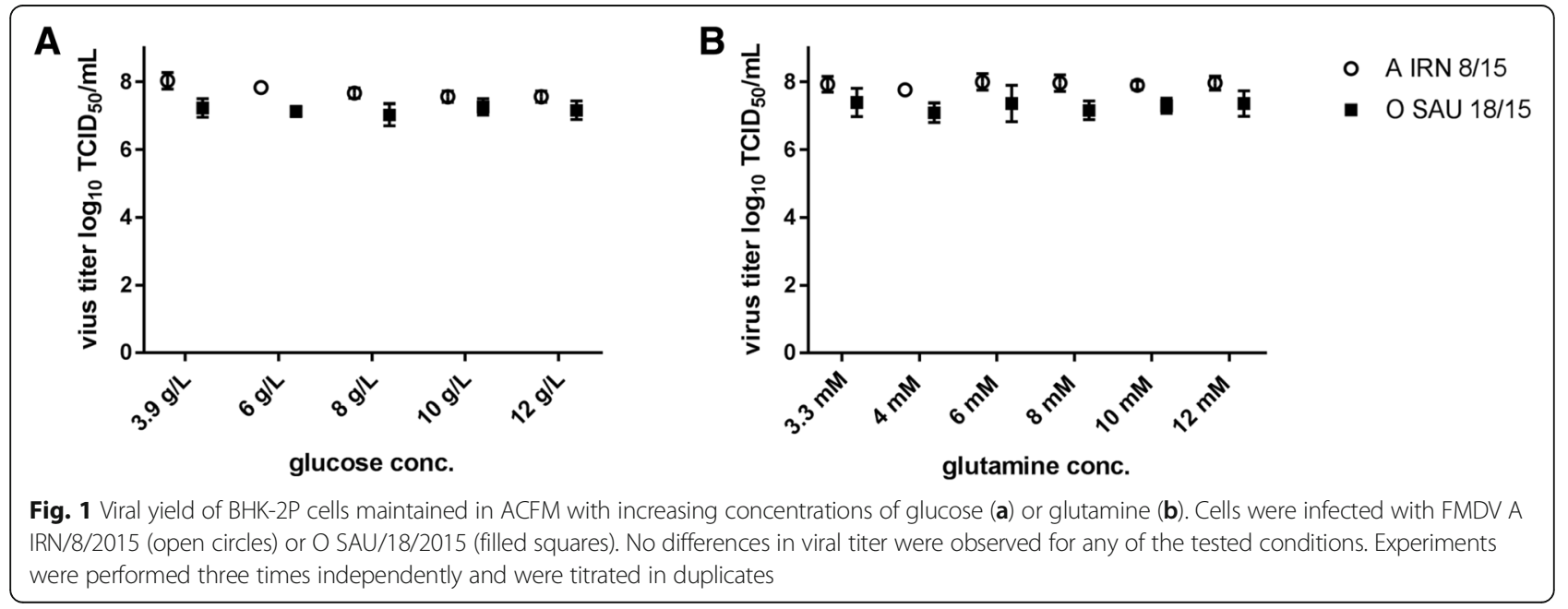




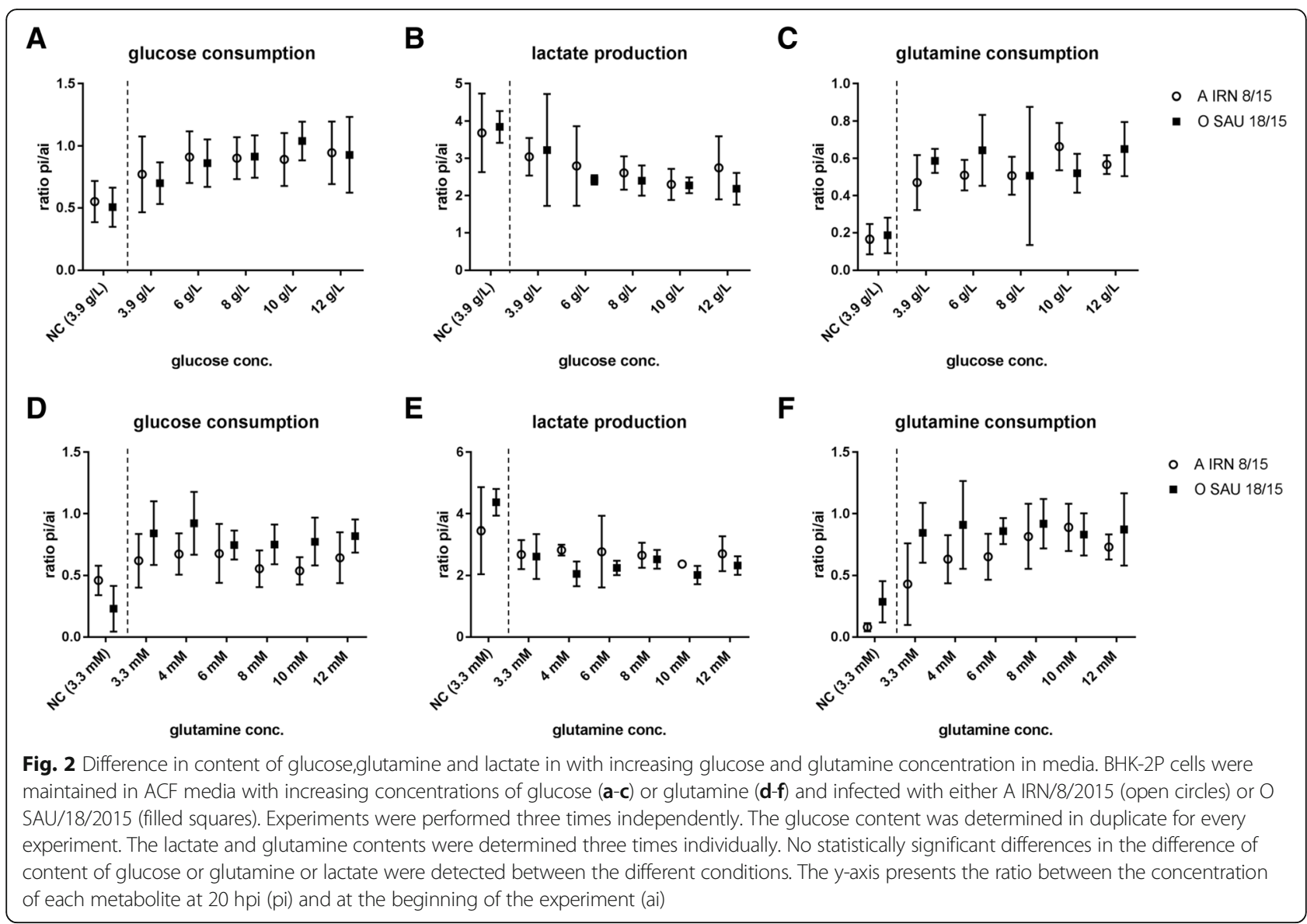

$8 / 2015$ or O SAU/18/2015. Surprisingly, the viral yield was stable at a titer of $7.2 \pm 0.1 \log _{10} \mathrm{TCID}_{50} /$ $\mathrm{mL}$ for A IRN 8/2015 and $6.9 \pm 0.2 \log _{10} \mathrm{TCID}_{50} / \mathrm{mL}$ for O SAU 18/2015, while cell viability at $20 \mathrm{hpi}$ increased with increasing concentrations of ammonium chloride. That increase was statistically significant in the case of A IRN 8/15 (Fig. 3).

The prolonged survival of the infected BHK-2P cells at or above an ammonium chloride concentration of $6 \mathrm{mM}$ is reflected in an increased content of glutamine and glucose as well as lactate in the cell culture media (Fig. 4) . The difference in the content of glucose in the cell culture media before and after infection does not vary strongly between infected and uninfected cells but the

Table 1 Mean glucose and glutamine content in the cell culture media of BHK-2P suspension cells when infected with FMDV

\begin{tabular}{llll}
\hline cells infected with & A IRN 8/15 & O SAU 18/15 & NC \\
\hline glucose $(\mathrm{g} / \mathrm{L})$ & $1.7 \pm 0.5$ & $1.0 \pm 0.6$ & $2.7 \pm 1.1$ \\
glutamine $(\mathrm{mM})$ & $1.8 \pm 0.7$ & $1.5 \pm 0.6$ & $2.9 \pm 0.4$
\end{tabular}

Cells were either infected with FMDV A IRN/8/2015 or O SAU/18/2015 or uninfected ( $N C=$ negative control). The content was calculated by subtracting the measured concentration of the analyte at $20 \mathrm{hpi}$ from the measured concentration before infection content of lactate is reduced in the cell culture media of FMDV-infected cells. The calculation of the cellspecific glucose and glutamine uptake as well as lactate production revealed an increasing trend for all three metabolites between a concentration of 2-10 $\mathrm{mM} \mathrm{NH} \mathrm{NH}_{4} \mathrm{Cl}$ in the media for cells infected with the FMDV A/IRN/8/2015 isolate, while no such trend was evident for cells infected with FMDV O/SAU/18/2015 (see Additional file 3: Table S5).

\section{Increased cell density leads to decreased viral yield}

Cell densities of $1 \times 10^{6}$ cells $/ \mathrm{mL}, 2 \times 10^{6}$ cells $/ \mathrm{mL}$ and $3 \times 10^{6}$ cells $/ \mathrm{mL}$ were infected with FMDV A IRN/8/ 2015 or O SAU/18/2015, either with a media exchange of $100 \%$ or with a media exchange of $30 \%$ before infection. Cell viability at 20 hpi was higher (Fig. 5) and viral titers were lower (Fig. 6) at higher cell densities when only $30 \%$ of the culture media was replaced with fresh media before infection. While differences in cell viability 20 hpi between 100 and 30\% media exchange are already evident for A IRN/8/2015 at a cell density of $2 \times 10^{6}$ cells $/ \mathrm{mL}$, a statistically significant difference in cell death was only seen between the $30 \%$ media exchange preparations of $1 \times 10^{6}$ cells $/ \mathrm{mL}$ and $3 \times 10^{6}$ cells $/ \mathrm{mL}$ for $\mathrm{O}$ 


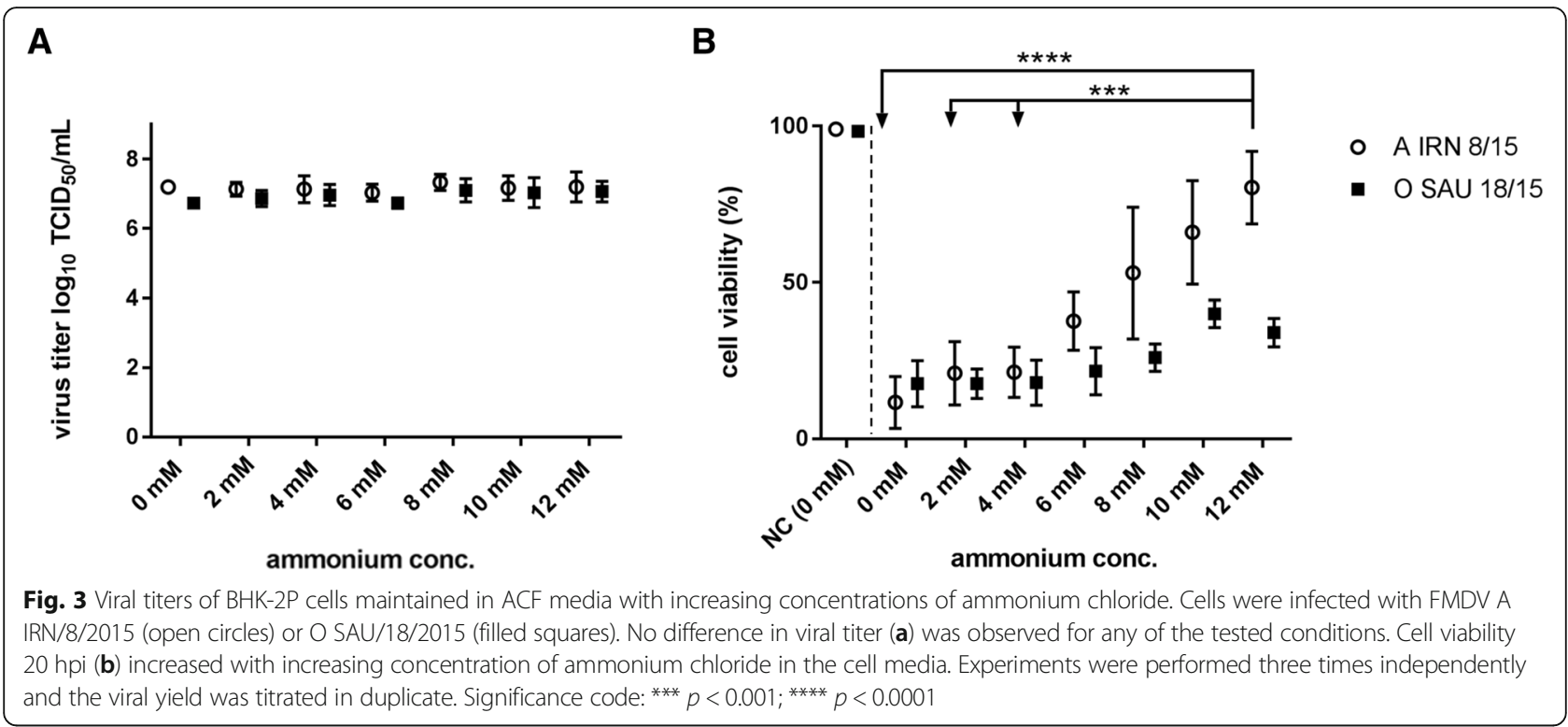

SAU/18/2015 (Fig. 5). No differences in the cell viability were detected when the full volume of medium was exchanged, independently of the cell density.

Viral titers of $7.7 \pm 0.3 \log _{10} \mathrm{TCID}_{50} / \mathrm{mL}$ for A IRN/8/ 2015 and $7.5 \pm 0.3 \log _{10} \mathrm{TCID}_{50} / \mathrm{mL}$ for O SAU/18/2015 were achieved at all tested cell densities if a $100 \%$ media exchange was performed. A slight increase in viral titer with increasing cell density was seen, but it was not statistically significant (see Additional file 2: Table S1). With a $30 \%$ media exchange before infection, stable titers of $8.1 \pm 0.0 \log _{10} \mathrm{TCID}_{50} / \mathrm{mL}$ for A IRN/8/2015 and $7.3 \pm 0.1 \log _{10} \mathrm{TCID}_{50} / \mathrm{mL}$ for $\mathrm{O}$ SAU/18/2015 were reached for densities of $1 \times 10^{6}$ cells $/ \mathrm{mL}$ and $2 \times 10^{6}$ cells $/ \mathrm{mL}$, while the viral titer significantly dropped by one $\log _{10}$ at a cell density of $3 \times 10^{6}$ cells $/ \mathrm{mL}$ (serotype
A: $7.0 \pm 0.6 \log _{10} \mathrm{TCID}_{50} / \mathrm{mL}$; serotype O: $6.7 \pm 0.3 \log _{10}$ $\mathrm{TCID}_{50} / \mathrm{mL}$ ) (Fig. 6).

The difference in the content of glucose, lactate and glutamine before and after viral infection was similar across the different cell densities when $100 \%$ of media were exchanged. Similar to the experiments with increasing glucose and glutamine concentrations in the media, only a small fraction of the provided carbohydrates was metabolized by the virus-infected cells. With an incomplete exchange of media (30\%), the difference in the contents of glucose and lactate in the cell culture media of the virus-infected cell cultures were similar to the negative controls. High values of lactate $(>10 \mathrm{mM})$ and a decreased $\mathrm{pH}$ of the culture media were already evident at a cell density of $1 \times 10^{6}$ cells $/ \mathrm{mL}$ (Table 2 ).

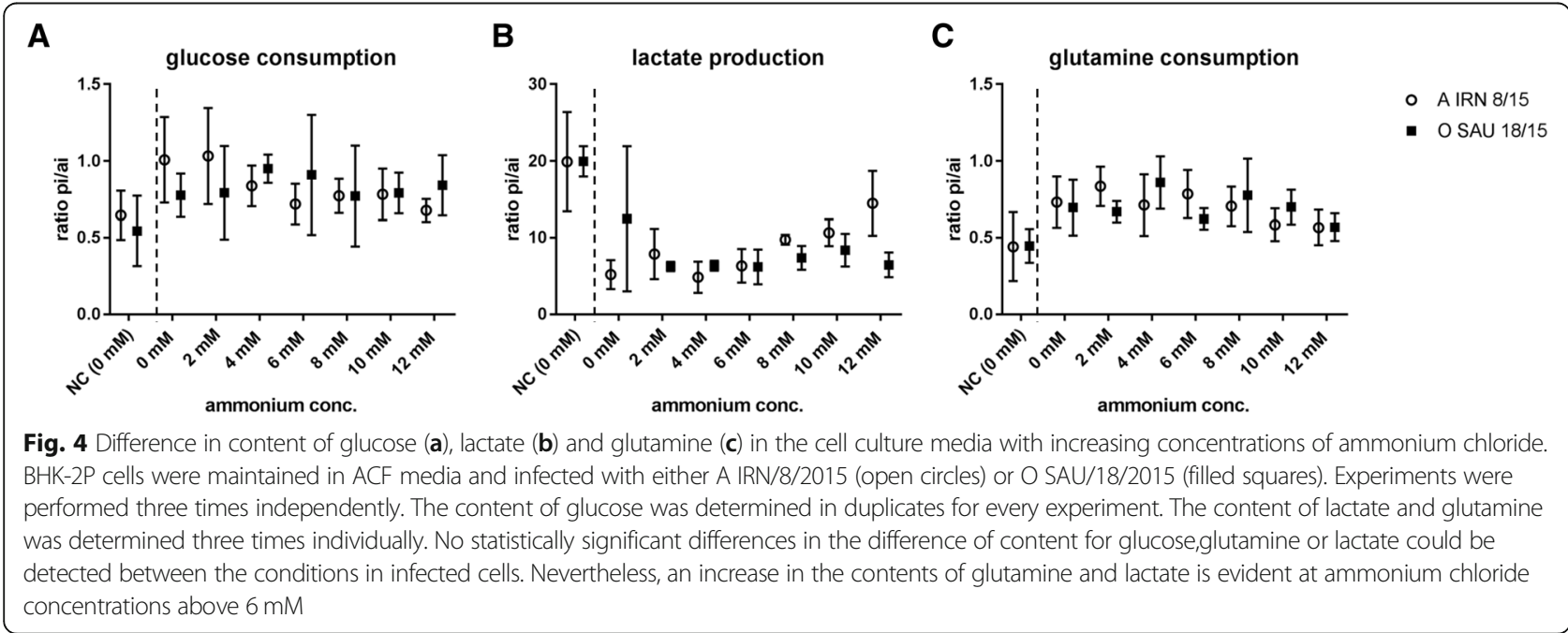



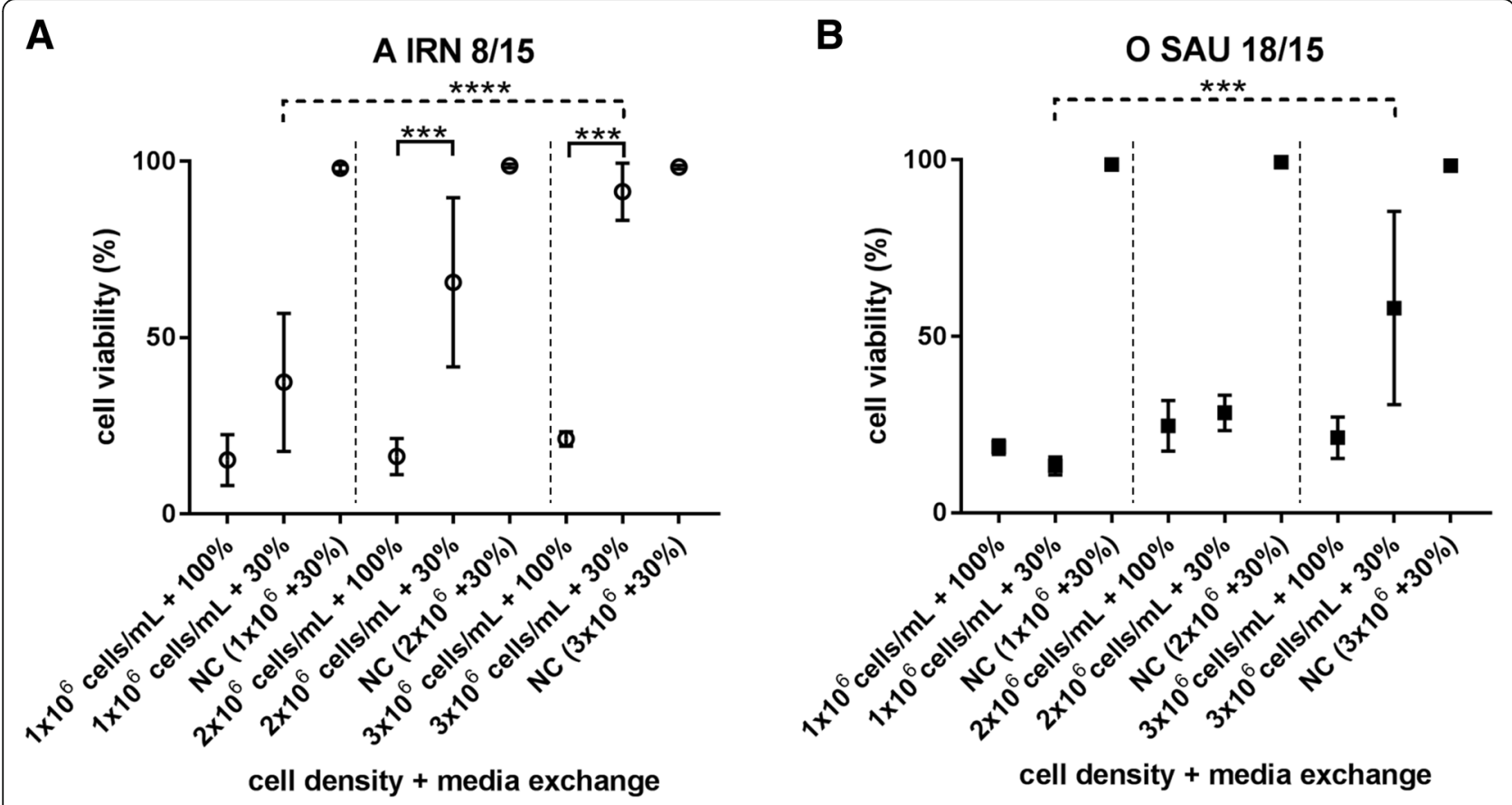

Fig. 5 Cell viability of BHK-2P cells at increasing densities and different media substitutions. A substitution of 30\% or 100\% fresh media was performed before infection. Cells were infected with FMDV A IRN/8/2015 (a) or O SAU/18/2015 (b). Significant differences in cell viability 20 hpi were detected between 30 and 100\% media substitution at cell densities of $2 \times 106$ cells/mL and $3 \times 106$ cells $/ \mathrm{mL}$ for A IRN/8/2015 and between the $30 \%$ media exchange preparations of $1 \times 106$ cells $/ \mathrm{mL}$ and $3 \times 106$ cells $/ \mathrm{mL}$ for O SAU/18/2015. Experiments were performed three times independently. Significance code: ${ }^{* * *} p<0.001 ;{ }^{* * *} p<0.0001$

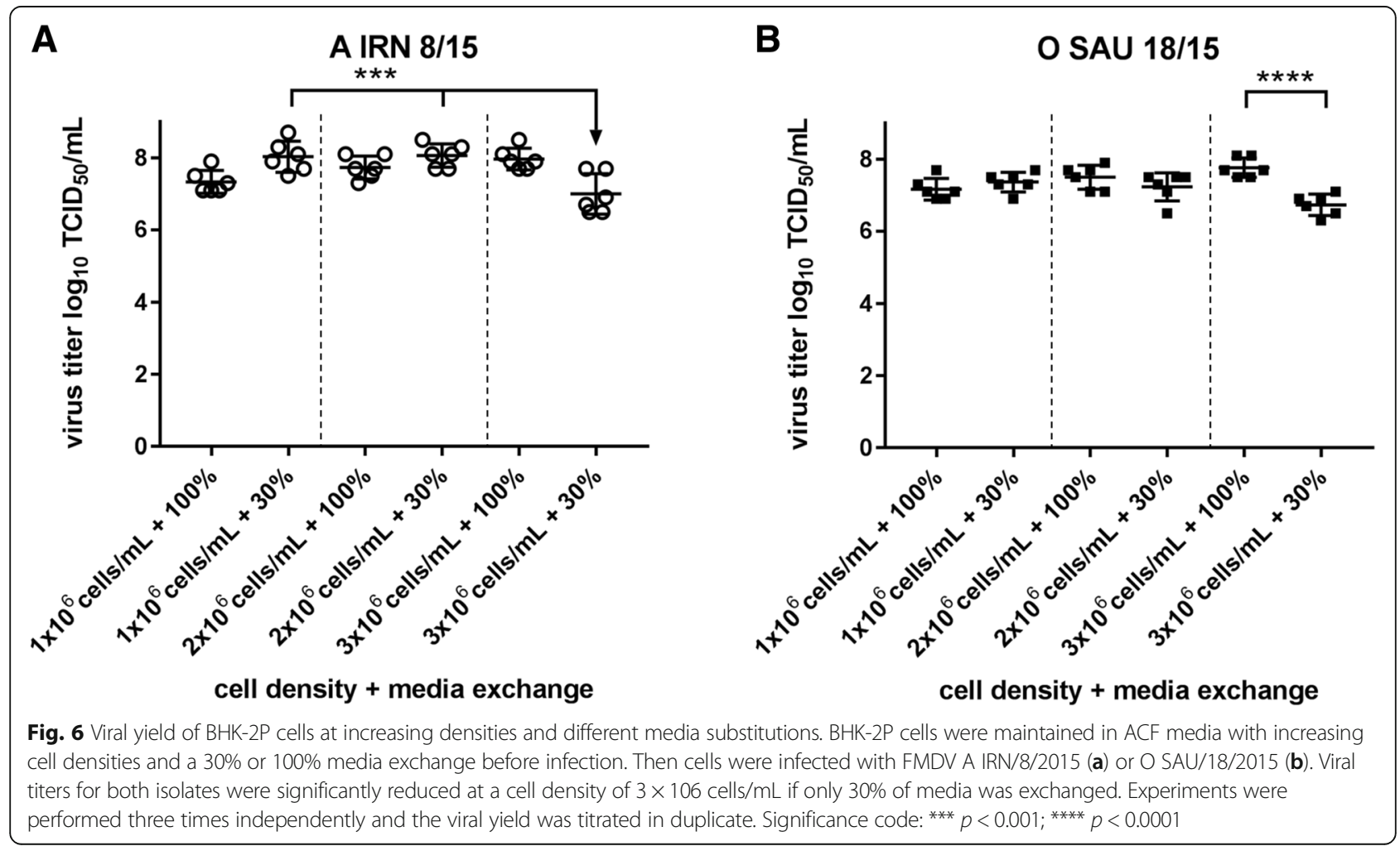


Table 2 Glucose, lactate, and glutamine content and $\mathrm{pH}$ of the ACF media $20 \mathrm{~h}$ after viral infection

\begin{tabular}{|c|c|c|c|c|c|c|c|c|c|}
\hline virus & \multicolumn{2}{|c|}{ A IRN/8/2015 } & NC & \multicolumn{2}{|c|}{ A IRN/8/2015 } & NC & \multicolumn{2}{|c|}{ A IRN/8/2015 } & $\mathrm{NC}$ \\
\hline cell density & \multicolumn{3}{|c|}{$1 \times 10^{6}$ cells $/ \mathrm{mL}$} & \multicolumn{3}{|c|}{$2 \times 10^{6}$ cells $/ \mathrm{mL}$} & \multicolumn{3}{|c|}{$3 \times 10^{6}$ cells $/ \mathrm{mL}$} \\
\hline media exchange & $100 \%$ & $30 \%$ & $30 \%$ & $100 \%$ & $30 \%$ & $30 \%$ & $100 \%$ & $30 \%$ & $30 \%$ \\
\hline $\mathrm{pH}$ & $7.5 \pm 0.1$ & $7.3 \pm 0.1$ & $7.1 \pm 0.2$ & $7.3 \pm 0.1$ & $7.0 \pm 0.1$ & $7.0 \pm 0.1$ & $7.2 \pm 0.1$ & $7.0 \pm 0.3$ & $6.9 \pm 0.1$ \\
\hline glucose (g/L) & $5.2 \pm 1.2$ & $3.4 \pm 1.0$ & $2.6 \pm 0.3$ & $3.7 \pm 1.8$ & $1.6 \pm 0.4$ & $1.4 \pm 0.6$ & $2.6 \pm 1.0$ & $1.1 \pm 0.5$ & $1.2 \pm 0.6$ \\
\hline lactate (mM) & $8.2 \pm 0.9$ & $23.0 \pm 6.1$ & $26.9 \pm 4.6$ & $16.6 \pm 3.1$ & $28.5 \pm 4.1$ & $29.2 \pm 3.5$ & $18.5 \pm 2.6$ & $25.1 \pm 5.3$ & $33.6 \pm 4.1$ \\
\hline glutamine (mM) & $2.5 \pm 1.8$ & $1.5 \pm 1.0$ & $0.4 \pm 0.3$ & $2.5 \pm 0.9$ & $0.6 \pm 0.6$ & $0.1 \pm 0.1$ & $1.6 \pm 0.6$ & $0.3 \pm 0.3$ & $0.7 \pm 0.9$ \\
\hline virus isolate & \multicolumn{2}{|c|}{ O SAU/18/2015 } & NC & \multicolumn{2}{|c|}{ O SAU/18/2015 } & NC & \multicolumn{2}{|c|}{ O SAU/18/2015 } & NC \\
\hline cell density & \multicolumn{3}{|c|}{$1 \times 10^{6}$ cells $/ \mathrm{mL}$} & \multicolumn{3}{|c|}{$2 \times 10^{6}$ cells $/ \mathrm{mL}$} & \multicolumn{3}{|c|}{$3 \times 10^{6}$ cells $/ \mathrm{mL}$} \\
\hline media exchange & $100 \%$ & $30 \%$ & $30 \%$ & $100 \%$ & $30 \%$ & $30 \%$ & $100 \%$ & $30 \%$ & $30 \%$ \\
\hline $\mathrm{pH}$ & $7.4 \pm 0.0$ & $7.4 \pm 0.0$ & $7.1 \pm 0.0$ & $7.4 \pm 0.0$ & $7.2 \pm 0.2$ & $7.0 \pm 0.2$ & $7.2 \pm 0.20$ & $6.9 \pm 0.2$ & $6.9 \pm 0.2$ \\
\hline glucose (g/L) & $7.0 \pm 1.6$ & $5.2 \pm 1.0$ & $3.5 \pm 1.0$ & $5.1 \pm 0.7$ & $3.1 \pm 1.2$ & $2.1 \pm 0.8$ & $4.1 \pm 0.3$ & $1.5 \pm 0.9$ & $1.6 \pm 0.5$ \\
\hline lactate (mM) & $7.5 \pm 4.1$ & $11.5 \pm 5.8$ & $21.4 \pm 10.7$ & $14.9 \pm 6.8$ & $23.7 \pm 11.1$ & $27.9 \pm 14.0$ & $16.6 \pm 8.4$ & $29.2 \pm 14.9$ & $36.8 \pm 19$ \\
\hline glutamine (mM) & $4.3 \pm 1.5$ & $3.1 \pm 0.9$ & $1.3 \pm 0.3$ & $4.0 \pm 1.3$ & $1.6 \pm 0.7$ & $0.5 \pm 0.4$ & $2.6 \pm 0.5$ & $0.7 \pm 0.3$ & $0.2 \pm 0.1$ \\
\hline
\end{tabular}

The depletion of glutamine in the virus-infected cell cultures with $30 \%$ media exchange was slightly less compared to the negative controls of the same cell density (Table 2). In general, glutamine in the negative cultures was almost completely depleted. The comparison of the cell-specific uptake rates showed a negative trend for the mock-infected cells and cells infected in $30 \%$ fresh media with reduced glucose consumption at higher cell densities, whereas cells infected in 100\% fresh media increased their glucose uptake (see Additional file 3: Table S6).

\section{Discussion}

Several studies have reported an increased uptake of glutamine and/or glucose in the course of a viral infection of cell cultures [13, 14]. Very little is known about the metabolic processes in an FMDV-infected cell culture or about the nutrient requirements for successful virus production. For poliomyelitis virus, another picornavirus, it is known that virus production depends on the media composition [4]. For that virus, it was hypothesized that glucose and glutamine are necessary as energy sources or for synthesis of the viral nucleic acid [5]. Of the two nutrients, glutamine was determined to be the more important factor, possibly due to the high inherent glutaminase activity of HeLa cells [4].

Conversely, for FMDV, an early study by Pledger and colleagues determined glucose as the only necessary factor for virus replication in primary bovine kidney cells [15]. The present study examined the possibility of increasing the FMD viral yield by providing more of these key nutrients in the culture media, but neither an increased concentration of glucose (up to $12 \mathrm{~g} / \mathrm{L}$ ) nor of glutamine (up to $12 \mathrm{mM}$ ) had a significant effect on the virus titer. In addition, no increase in glycolysis or glutaminolysis of the cell was observed. Darnell and colleagues have proposed that the optimal glucose and glutamine concentrations for virus production are the same as for cell growth [4]. Comparing the residual content of glucose and glutamine in the media between a mature infected culture and the corresponding negative control revealed that only a small fraction of the supplied nutrients had been metabolized. As previously proposed by Pledger et al., extracellular nutrient requirements seem to be of lesser importance for FMD virus particle production [15]. A possible explanation for this is the rapid growth of FMDV in infected cells. While one replication cycle of poliovirus takes 3-7.5 $\mathrm{h}$ (depending on the cell line), FMDV only needs 1.5 to $2.5 \mathrm{~h}$ to replicate in primary bovine kidney cells [15] and the first newly produced virus particles usually appear in the culture media after 4-6h [18]. Due to the rapid progression of lytic infection, most cells in the culture vessel are dead before the available nutrients are exhausted. Consequently, metabolic waste products such as lactate were not sufficiently increased to lower the $\mathrm{pH}$ to a level that would negatively impact the viral yield. FMDV particles are highly acid-sensitive and the capsid dissociates at $\mathrm{pH}$ values slightly below neutrality $(<\mathrm{pH} 6.8)$ [19]. In the course of infection in this study, the $\mathrm{pH}$ of the media decreased from 7.5 to at most 7.2, which has no impact on the stability of virus particles.

To initiate infection, FMDV releases its genome into the host cell by dissociation of the capsid into pentameric subunits, which is triggered by the acidification of the endosome [20]. Ammonium ions $\left(\mathrm{NH}_{4}^{+}\right)$, a waste product of the glutamine metabolism pathway, neutralize the acidic $\mathrm{pH}$ within endosomes and block the uncoating of the viral 
RNA [21]. Surprisingly, we found no difference in the viral titers in cultures supplemented with increasing concentrations of ammonium chloride (up to $12 \mathrm{mM}$ ). At the same time, the cell viability in infected cultures increased dramatically at higher concentrations of ammonium chloride, particularly for the serotype A virus isolate.

Several studies have been performed to examine the effect of lysosomotropic agents on FMDV infection [20-23]. In most cases, only concentrations of $25 \mathrm{mM}$ and $50 \mathrm{mM}$ ammonium chloride were tested and these resulted in a drastically reduced viral titer at 25 $\mathrm{mM}$ and a complete block of infection at $50 \mathrm{mM}$ $\mathrm{NH}_{4} \mathrm{Cl}$ [20]. Carillo et al. tested the influence of lower concentrations of ammonium chloride (10, 20 and $30 \mathrm{mM}$ ), leading to a $95 \%$ reduction in the viral yield for $30 \mathrm{mM}$ and a proportionally lower impact for $20 \mathrm{mM}$ and $10 \mathrm{mM}$ [21]. No data are available for batch cultures of BHK cells infected with FMDV, but glutamine metabolism and ammonium production during cell growth and virus infection in batch culture are well studied for MDCK cells and influenza virus [24]. Similar to the observations for conventional FMDV culture, a reduction in the yield of influenza virus was evident for $\mathrm{NH}_{4} \mathrm{Cl}$ concentrations above $20 \mathrm{mM}$. However, this is not likely to have an effect under real production conditions. In theory, a maximum of $4 \mathrm{mM}$ ammonium can be produced from the $4 \mathrm{mM}$ glutamine available at the start of the process [24], but in the experiment, no more than 2 $\mathrm{mM}$ of ammonium were produced by the cells throughout the entire process [24]. Considering the rapid progression of FMDV infection, it is unlikely that the real ammonium concentrations produced during FMDV antigen production exceed these values and thus influence the yield. Nevertheless, in the absence of a satisfactory explanation for the increased cell viability observed at higher concentrations, production processes should be controlled in such a way that not more than $6 \mathrm{mM}$ ammonium can accumulate in the culture media before viral infection.

Several studies have reported so-called "cell density effects" in different culture systems used for virus production $[16,25,26]$. For our studies, three different cell densities $\left(1 \times 10^{6}\right.$ cells $/ \mathrm{mL}, 2 \times 10^{6}$ cells $/ \mathrm{mL}$ and $3 \times 10^{6}$ cells $/ \mathrm{mL}$ ) with either $100 \%$ or $30 \%$ media exchange before infection were tested. No difference in viral titer was detected between the different cell densities if a full media exchange was performed. An exchange of $30 \%$ of the media led to a high variability in cell viability at the end of the process and together with a cell density of $3 \times 10^{6}$ cells $/ \mathrm{mL}$ reduced the final viral titer by about one $\log _{10}$ step. This may be due to nutrient limitation or the accumulation of inhibitory factors $[16,25]$, but the exact cause of the specific "cell density effect" observed in our system is unknown. The lactate content was elevated in cultures with $3 \times 10^{6}$ cells $/ \mathrm{mL}$ and $30 \%$ media exchange, but it is unlikely that this directly influenced infectivity. The $\mathrm{pH}$ of the culture medium was adjusted to $\mathrm{pH} 7.5$ before infection and high concentrations of lactate alone do not impair the growth of BHK cells [27]. With only $30 \%$ of media being replaced, glucose and especially glutamine levels are reduced compared to cultures with a full exchange, but the available nutrients should be still sufficient for virus production. Further experiments are needed to examine whether this effect is still visible if the concentrations of glucose and glutamine are increased at the time of infection.

The examination of cell growth rates at the different conditions could also offer valuable information about the ability of the cells to produce virus. An inhibited cell growth can be linked to reduced virus production. In addition, it is known that the impact of excessive cell densities on production depends on the culture medium [25]. It would be of interest if other culture media can mitigate the "cell density effect" and further improve FMDV vaccine production processes.

\section{Conclusions}

This study determined important culture parameters that influence FMDV titers in a small-scale bioreactor system. While an excess of glucose, glutamine and ammonia in the culture media does not directly influence the viral yield, the cell density seems to have the largest impact on the viral titers achieved in batch culture. Further experiments have to be performed to study the nature of this effect in greater detail. Based on the current state of knowledge, $100 \%$ media exchange is recommended for optimal yield and high reproducibility.

\section{Methods}

All experiments have been performed in a veterinary BSL-4 laboratory that meets the Minimum Biorisk Management Standards for Laboratories Working with FMDV [28].

\section{Cells}

The suspension cell line BHK21C13-2P (in short: BHK2P; originally derived from the European Collection of Authenticated Cell Cultures specimen 84,111,301) was adapted to grow in Cellvento ${ }^{\text {TM }}$ BHK-200 (Merck KGaA, Darmstadt, Germany) ACF medium in TubeSpin ${ }^{\circ}$ bioreactors (TPP Techno Plastic Products AG, Trasadingen, Switzerland). The cells were maintained in a shaker incubator at $320 \mathrm{rpm}(\mathrm{rpm})$ at $37^{\circ} \mathrm{C}, 5 \% \mathrm{CO}_{2}$ and $80 \%$ relative humidity.

For virus titrations, the adherent BHK21 clone "Tübingen" cell line (in short: BHK164, specimen CCLV-RIE 164 in the Collection of Cell Lines in Veterinary Medicine, Friedrich-Loeffler-Institut [FLI], Greifswald, Germany) was 
cultured in Minimum Essential Medium Eagle, supplemented with Hanks' and Earle's salts (Sigma-Aldrich, St. Louis, USA) with $5 \%$ fetal bovine serum. The adherent cells were incubated at $37^{\circ} \mathrm{C}$ and $5 \% \mathrm{CO}_{2}$.

\section{Viruses and virus titrations}

The FMDV isolates A IRN/8/2015 and O SAU/18/2015 were selected from archival stocks at the FLI. Their origin and passage history can be found in Additional file 2: Table S2 Viral titers were estimated by endpoint titration with the Spearman-Kärber method [29, 30] and expressed as $50 \%$ tissue culture infectious dose (TCID50) per milliliter. Virus titrations were performed on the adherent BHK164.

\section{Small-scale bioreactor experiments}

All experiments were performed in TubeSpin Bioreactors50 (TPP) with a working volume of $30 \mathrm{ml} . \mathrm{pH}$ measurements before infection were performed with a potentiometric $\mathrm{pH}$ meter (Mettler Toledo, Gießen, Germany) and if necessary the $\mathrm{pH}$ was adjusted to 7.5 using $1 \mathrm{M}$ sodium hydroxide. Cells were infected at a multiplicity of infection (MOI) of 0.1 , and virus was harvested after $20 \mathrm{~h}$ of incubation. Virus samples were stored at $-70^{\circ} \mathrm{C}$, then thawed for further processing and cell debris were removed by centrifugation at $3200 \times \mathrm{g}$ for $10 \mathrm{~min}$ at $4{ }^{\circ} \mathrm{C}$. Samples to determine the content of glucose, lactate and glutamine were taken from the bioreactor immediately before infection and again $20 \mathrm{~h}$ post infection (hpi). These samples were centrifuged at $155 \times \mathrm{g}$ for $5 \mathrm{~min}$ at $4{ }^{\circ} \mathrm{C}$ and the supernatant was stored at $-70{ }^{\circ} \mathrm{C}$ until further processing. $\mathrm{pH}$ measurements $20 \mathrm{hpi}$ were performed using single-use $\mathrm{pH}$ test strips (range 6.5-10, Merck KGaA, Darmstadt, Germany) for biosafety reasons.

\section{Glucose}

TubeSpin cultures were seeded with $0.5 \times 10^{6}$ cells/ $\mathrm{mL}$. The cells were pelleted at $290 \times \mathrm{g}$ for $5 \mathrm{~min}$ and resuspended in $100 \%$ fresh media with different glucose concentrations $(3.9 \mathrm{~g} / \mathrm{L}, 6 \mathrm{~g} / \mathrm{L}, 8 \mathrm{~g} / \mathrm{L}, 10 \mathrm{~g} / \mathrm{L}$, $12 \mathrm{~g} / \mathrm{L}$ ). The cultures were placed in the shaker incubator overnight until a cell density of $1 \times 10^{6}$ cells $/ \mathrm{mL}$ was reached. Then the cells were pelleted again and $30 \%$ of the culture media were replaced with fresh media supplemented with the respective glucose concentration. After the 30\% media exchange, the $\mathrm{pH}$ was adjusted to 7.5 if necessary and the cells were infected with FMDV A IRN/8/2015 or O SAU/18/ 2015. An uninfected negative control with standard conditions $(3.9 \mathrm{~g} / \mathrm{L}$ glucose) was also included. The experiment was performed three times independently.

\section{Glutamine}

TubeSpin cultures were seeded with $0.5 \times 10^{6}$ cells $/ \mathrm{mL}$, cells were pelleted at $290 \times \mathrm{g}$ for $5 \mathrm{~min}$ and resuspended in $100 \%$ fresh media with different glutamine concentrations $(3.3 \mathrm{mM}, 4 \mathrm{mM}, 6 \mathrm{mM}, 8 \mathrm{mM}, 10 \mathrm{mM}, 12 \mathrm{mM})$. The cultures were placed in the shaker incubator overnight until a cell density of $1 \times 10^{6}$ cells $/ \mathrm{mL}$ was reached. Then the cells were pelleted again and 30\% of the culture media were replaced with fresh media, supplemented with the respective glutamine concentration. After the $30 \%$ media exchange, the $\mathrm{pH}$ was adjusted to 7.5 if necessary and the cells were infected with FMDV A IRN/8/2015 or O SAU/18/2015. An uninfected negative control with standard conditions $(3.3 \mathrm{mM}$ glutamine) was also included. The experiment was performed three times independently.

\section{Ammonium chloride}

TubeSpin cultures were inoculated with $1 \times 10^{6}$ cells/ $\mathrm{mL}$, the cells were pelleted at $290 \times \mathrm{g}$ for $5 \mathrm{~min}$ and resuspended in $100 \%$ fresh media supplemented with different concentrations of ammonium chloride $(0 \mathrm{mM}$, $2 \mathrm{mM}, 4 \mathrm{mM}, 6 \mathrm{mM}, 8 \mathrm{mM}, 10 \mathrm{mM}, 12 \mathrm{mM}$ ). After resuspension of the cells, the $\mathrm{pH}$ was adjusted to 7.5 if necessary and the cells were infected with FMDV A IRN/8/2015 or O SAU/18/2015. An uninfected negative control with standard conditions (no ammonium chloride) was also included. The experiment was performed three times independently.

\section{Cell density}

TubeSpin cultures were inoculated with $0.5 \times 10^{6}$ cells/ $\mathrm{mL}, 1.0 \times 10^{6}$ cells $/ \mathrm{mL}$ or $1.5 \times 10^{6}$ cells $/ \mathrm{mL}$. The cells were pelleted at $290 \times \mathrm{g}$ for $5 \mathrm{~min}$ and resuspended in $100 \%$ fresh media. The cultures were placed in the shaker incubator overnight to reach cell densities of $1 \times$ $10^{6}, 2 \times 10^{6}$ and $3 \times 10^{6}$ cells $/ \mathrm{mL}$, respectively. Then the cells were pelleted again and a media exchange of $100 \%$ or $30 \%$ was performed. After resuspension of the cells, the $\mathrm{pH}$ was adjusted to 7.5 if necessary and the cells were infected with FMDV A IRN/8/2015 or O SAU/18/ 2015. An uninfected negative control was also included. In total, three tubes per density were prepared: one tube with virus and $30 \%$ media exchange, one tube with virus and $100 \%$ media exchange, and one tube with no virus and $30 \%$ media exchange. The experiment was performed three times independently.

\section{Assays}

Cell concentration and viability were assessed using a trypan blue dye exclusion method with an automated cell counter (TC20 ${ }^{\mathrm{mm}}$, Bio-Rad, Munich, Germany). Glucose, lactate and glutamine concentrations were determined using quantitative colorimetric assays (EnzyChrom ${ }^{\text {th }}$ 
EBGL-100, EGLN-100 or ECLC-100, BioAssay Systems, Hayward, USA) as directed by the manufacturer.

\section{Statistical analysis}

In all experiments, the differences between treatment groups were evaluated using one-way ANOVA, combined with Tukey's multiple comparisons test in GraphPad Prism 7 (www.graphpad.com). $p$-values of $<0.001$ were considered significant.

\section{Additional files}

Additional file 1: Figure S1. Cell viability $20 \mathrm{hpi}$ with FMDV in media with increasing concentrations of glucose (A) or glutamine (B). (TIF 770 $\mathrm{kb})$

Additional file 2: Table S1. Mean viral titers and standard deviation of cell density experiments. Table S2. Overview about the original virus isolates used in this study, their origin and passage history. (XLS 44 kb)

Additional file 3: Table S3. Cell-specific uptake and release rates of extracellular metabolites of infected BHK-2P cells and corresponding negative control with increasing extracellular glucose concentrations. Table S4. Cell-specific uptake and release rates of extracellular metabolites of infected BHK-2P cells and corresponding negative control with increasing extracellular glutamine concentrations. Table S5. Cell-specific uptake and release rates of extracellular metabolites of infected BHK-2P cells and corresponding negative control with increasing extracellular ammonium concentrations. Table S6. Cell-specific uptake and release rates of extracellular metabolites of infected BHK-2P cells and corresponding negative control at different cell densities and media exchange strategies. (XLSX 18 kb)

\section{Abbreviations}

ACF: animal-component free; ANOVA: analysis of variance; BHK: baby hamster kidney; BHK-2P: BHK21C13-2P; CCLV-RIE: Collection of Cell Lines in Veterinary Medicine; FLI: Friedrich-Loeffler-Institut; FMD(V): foot-and-mouth disease (virus); hpi: hours post infection; MDCK: Madin-Darby Canine Kidney; MOl: multiplicity of infection; $\mathrm{NH}_{4} \mathrm{Cl}$ : ammonium chloride; $\mathrm{RNA}$ : ribonucleic acid; $\mathrm{TCID}_{50}$ : $50 \%$ tissue culture infectious dose

\section{Acknowledgements}

Not applicable.

\section{Authors' contributions}

VD performed the experiments and calculations, interpreted the data and drafted the manuscript. AZ contributed to the conception of the study and edited the manuscript. MB edited the manuscript. ME edited the manuscript and generally supervised the project. All authors read and approved the final manuscript.

\section{Funding}

The study was funded by Merck Life Science as part of the third-party project "MKS-Growth" (Ri-0367). Merck Life Science had no role in the collection, analysis, or interpretation of data and in the writing of the manuscript.

\section{Availability of data and materials}

All data generated or analysed during this study are included in this published article. Raw data are available from the corresponding author on reasonable request.

\section{Ethics approval and consent to participate}

Not applicable.

\section{Consent for publication}

Not applicable.

\section{Competing interests}

$\mathrm{MB}$ and $\mathrm{ME}$ declare that they have no competing interests. VD's position was funded by the project. AZ is an employee of Merck Life Science.

\section{Author details}

'Institute of Diagnostic Virology, Friedrich-Loeffler-Institut, Südufer 10, 17493 Greifswald, Insel Riems, Germany. ${ }^{2}$ Merck KGaA, Merck Life Sciences, Upstream R\&D, Frankfurter Straße, 250, 64293 Darmstadt, Germany.

Received: 31 July 2018 Accepted: 20 May 2019

Published online: 07 June 2019

\section{References}

1. Thompson D, Muriel P, Russell D, Osborne P, Bromley A, Rowland M, et al. Economic costs of the foot and mouth disease outbreak in the United Kingdom in 2001. Rev Sci Tech. 2002;21(3):675-87.

2. Spitteler MA, Fernandez I, Schabes E, Krimer A, Regulier EG, Guinzburg M, et al. Foot and mouth disease (FMD) virus: quantification of whole virus particles during the vaccine manufacturing process by size exclusion chromatography. Vaccine. 2011;29(41):7182-7.

3. Doel TR. FMD vaccines. Virus Res. 2003;91(1):81-99.

4. Darnell JE Jr, Eagle $\mathrm{H}$. Glucose and glutamine in poliovirus production by HeLa cells. Virology. 1958;6(2):556-66.

5. Eagle $H$, Habel K. The nutritional requirements for the propagation of poliomyelitis virus by the HeLa cell. J Exp Med. 1956;104(2):271-87.

6. Cruz HJ, Moreira JL, Carrondo MJ. Metabolic shifts by nutrient manipulation in continuous cultures of BHK cells. Biotechnol Bioeng. 1999;66(2):104-13.

7. Baggetto LG. Deviant energetic metabolism of glycolytic cancer cells. Biochimie. 1992;74(11):959-74.

8. Levy HB, Baron S. The effect of animal viruses on host cell metabolism. II. Effect of poliomyelitis virus on glycolysis and uptake of glycine by monkey kidney tissue cultures. J Infect Dis. 1957;100(2):109-18.

9. Bardell D, Essex M. Glycolysis during early infection of feline and human cells with feline leukemia virus. Infect Immun. 1974;9(5):824-7.

10. Gray MA, James MH, Booth JC, Pasternak CA. Increased sugar transport in BHK cells infected with Semliki Forest virus or with herpes simplex virus. Arch Virol. 1986;87(1-2):37-48.

11. Fontaine KA, Camarda R, Lagunoff M. Vaccinia virus requires glutamine but not glucose for efficient replication. J Virol. 2014:88(8):4366-74.

12. Munger J, Bajad SU, Coller HA, Shenk T, Rabinowitz JD. Dynamics of the cellular metabolome during human cytomegalovirus infection. PLoS Pathog. 2006;2(12):e132.

13. Sanchez EL, Lagunoff M. Viral activation of cellular metabolism. Virology. 2015;479-480:609-18.

14. Maynard ND, Gutschow MV, Birch EW, Covert MW. The virus as metabolic engineer. Biotechnol J. 2010;5(7):686-94.

15. Pledger RA, Polatnick J. Defined medium for growth of foot-and-mouth disease virus. J Bacteriol. 1962:83:579-83.

16. Thomassen $Y E$, Rubingh $\mathrm{O}$, Wijffels RH, van der Pol LA, Bakker WA. Improved poliovirus D-antigen yields by application of different Vero cell cultivation methods. Vaccine. 2014;32(24):2782-8.

17. Genzel Y, Fischer M, Reichl U. Serum-free influenza virus production avoiding washing steps and medium exchange in large-scale microcarrier culture. Vaccine. 2006:24(16):3261-72.

18. Grubman MJ, Baxt B. Foot-and-mouth disease. Clin Microbiol Rev. 2004; 17(2):465-93.

19. Caridi F, Vazquez-Calvo A, Sobrino F, Martin-Acebes MA. The pH stability of foot-and-mouth disease virus particles is modulated by residues located at the Pentameric Interface and in the N terminus of VP1. J Virol. 2015;89(10):5633-42.

20. Martin-Acebes MA, Gonzalez-Magaldi M, Sandvig K, Sobrino F, ArmasPortela R. Productive entry of type $C$ foot-and-mouth disease virus into susceptible cultured cells requires clathrin and is dependent on the presence of plasma membrane cholesterol. Virology. 2007;369(1):105-18.

21. Carrillo EC, Giachetti C, Campos RH. Effect of lysosomotropic agents on the foot-and-mouth disease virus replication. Virology. 1984;135(2):542-5.

22. Martin-Acebes MA, Rincon V, Armas-Portela R, Mateu MG, Sobrino F. A single amino acid substitution in the capsid of foot-and-mouth disease virus can increase acid lability and confer resistance to acid-dependent uncoating inhibition. J Virol. 2010;84(6):2902-12.

23. Baxt B. Effect of lysosomotropic compounds on early events in foot-and mouth disease virus replication. Virus Res. 1987:7(3):257-71.

24. Genzel Y, Behrendt I, Konig S, Sann H, Reichl U. Metabolism of MDCK cells during cell growth and influenza virus production in large-scale microcarrier culture. Vaccine. 2004;22(17-18):2202-8. 
25. Kamen A, Henry O. Development and optimization of an adenovirus production process. J Gene Med. 2004;6(Suppl 1):S184-92.

26. Wood HA, Johnston LB, Burand JP. Inhibition of Autographa californica nuclear polyhedrosis virus replication in high-density Trichoplusia ni cell cultures. Virology. 1982;119(2):245-54.

27. Hassell T, Gleave S, Butler M. Growth inhibition in animal cell culture. The effect of lactate and ammonia. Appl Biochem Biotechnol. 1991;30(1):29-41.

28. European Commision for the Control of Foot-and-Mouth Disease. Minimum biorisk management standards for laboratories working with foot-and-mouth disease virus Italy 2013 Available from: http:/wwww.fao.org/fileadmin/user_ upload/eufmd/Lab_guidelines/FMD_Minimumstandards_2013_Final_version.pdf.

29. Spearman C. The method of "right and wrong cases" (constant stimuli) without Gauss's formula. Br J Psychol. 1908;2:227-42.

30. Kärber G. Beitrag zur kollektiven Behandlung pharmakologischer Reihenversuche. Archiv f experiment Pathol u Pharmakol. 1931;162:480-3.

\section{Publisher's Note}

Springer Nature remains neutral with regard to jurisdictional claims in published maps and institutional affiliations.

Ready to submit your research? Choose BMC and benefit from:

- fast, convenient online submission

- thorough peer review by experienced researchers in your field

- rapid publication on acceptance

- support for research data, including large and complex data types

- gold Open Access which fosters wider collaboration and increased citations

- maximum visibility for your research: over $100 \mathrm{M}$ website views per year

At $\mathrm{BMC}$, research is always in progress.

Learn more biomedcentral.com/submissions 